\title{
食道離断術前後の食道機能
}

\author{
熊本大学第 1 外科 \\ 大熊 利忠 鳥越 義継 夏山 秀康 \\ 田代 征記 横山 育三* \\ (*前 熊本大学第 1 外科教室)
}

\section{ESOPHAGEAL FUNCTION IN PATIENTS WITH ESOPHAGEAL VARICES BEFORE AND AFTER ESOPHAGEAL TRANSECTION}

\section{Toshitada OKUMA, Yoshitsugu TORIGOE, Hideyasu NATSUYAMA, Seiki TASHIRO and Ikuzo YOKOYAMA*}

1 st Department of Surgery Kumamoto University Medical School, Kumamoto

(*past professor of the lst Department of Surgery Kumamoto University Medical School)

食道静脈瘤56症例の食道離断術前後の食道機能につき検討した，術前では下部食道括約筋(LES)の 機能もよく保たれ LES 圧は29.8 $55.7 \mathrm{~cm} \mathrm{H}_{2} \mathrm{O}(\mathrm{n}=16)$ でわれわれの normal controle $31.3 \pm 5.7 \mathrm{~cm} \mathrm{H}_{2}$ $\mathrm{O}(\mathrm{n}=10)$ と有意差がなかった。術後では LES 機能は低下し $33 \sim 43 \%$ 亿線造影で逆流がみられ LES

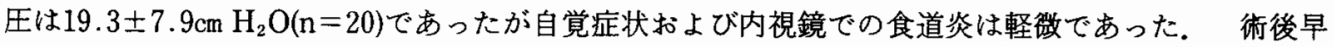
期の燕下障害の原因には下部食道のアカラシア様变化が関与している。離断物合部の狭窄は $42.9 \%$ に発生し, $10 \mathrm{~cm}$ 以上の傍食道血行郭清は広すぎると考えられた. 自動吻合器 $\mathrm{EEA}$ 使用症例に狭窄発生 率が高い傾向であったが統計的に手縫い結節吻合と有意差はなかった。

索引用語：食道離断術前後の食道機能, 食道静脈瘤, LESP, 下部食道のアカラシア様変化,

\section{I はじめに}

食道静脈瘤の外科治療としての食道離断術は胃上部 から胸腔内食道に至る広範囲の血行郭清が行われるた めの食道胃接合部 (以下 EGJ と略す) の解剖学的構造 は破壊され，さらに同部の阻血と denervation による 影響など, 術後の食道機能に幾多の問題をかかえてい る。ことに術後の逆流性食道炎和よび燕下障害が主な ものであり,これらに関し術前, 術後に亘り自覚症状, X線造影捛よびVTR, 食道内視鏡, さらに食道内王検 查などにより検討を行った。

\section{II 方法および対象症例}

当施設において食道離断術はこれまでに3つの到達 法により行われた（図 1).

(1) 径胸的到達法: 肝機能障害が強い poor risk 症 例に対し開腹操作は行わず左開胸だけで胸腔内の傍食 道の血行郭清と食道離断を行ら方法

(2) 径胸腹到達法：左開胸開腹を別々の皮切で行う
因 1 食道離断術後の各到達法之各手術操作

\section{径胸的到蚊法}
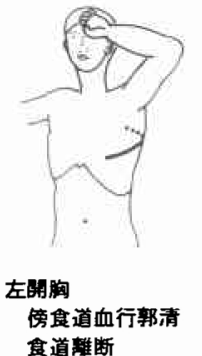

傍食道血行
食道離断
径胸腹到遣法
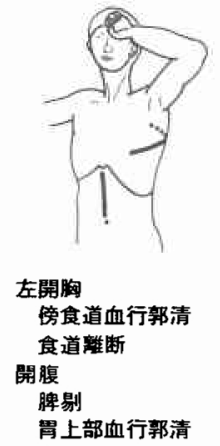

径胸腹横傮膜 切踓到途法

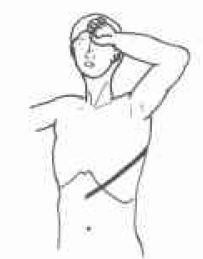

左開胸腹横倩膜切離 脾剔 筒上部傍食道血行郭祖 食道離断
東大 2 外科法でまず右側卧位にて左開胸を行い胸腔内 の傍食道の血行郭清々食道離断を行う。次仰仰臥位に 体位を変換し上腹部正中切開を行い脾剔と胃上部およ 
び腹部傍食道の血行郭清を行う。この開胸開腹操作を 一期に行う場合もあり,二期に分けて行う場合もある. (3) 径胸腹横隔膜切離到達法: 右側臥位にて左第 7 肋間開胸の皮切をそのまま腹部正中線まで延長し肋骨 弓を約 $2.0 \mathrm{~cm}$ 切除し開胸開腹を同一皮切で行5.横隔膜 を胁骨弓附着縁に沿って切離する，脾剔，胃上部から 腹部さらに胸部下部食道の血行を郭清し，食道離断を 同一術野で一挙に行ら。

当施設では食道離断術の標準術式としては以前は径 胸腹到達法を行ってきたが，1977年以来肝への影響が 少ない径胸腹横隔膜切離到達法を行っている1).

血行郭清の範囲は胃小弯側では Crow's foot の第 1 枝の口側の血管から上方を郭清し, 大弯側では左右胃 大網動脈分岐部より上方を郭清する。食道側は His 角 より口側に $10 \sim 17 \mathrm{~cm}$ 範囲の血行郭清が行われた。

径胸的到達法では当然胃側の血行郭清は行えない。 径胸腹横隔膜切離到達法では食道裂孔部の操作を行う にあたり胸腔側および腹腔側を同一視野で行うことが でき, 径胸腹到達法に比し食道裂孔部周囲の血行郭清 がより徹底して行われるようになった。そのため食道 裂孔部構造の破壊の程度は径胸的到達法, 径胸腹到達 法, 径胸腹横隔膜切離到達法の順に大きいもの之考学 られる。

対象例は1974年 1 月から1981年 1 月までの症例で径 胸的到達法14例, 径胸腹到達法13例, 径胸腹横隔膜切 離到達法29例の計56症例であり観察期間は術後 3 カ月 から 7 年である.

\section{III 成 績}

1 術前食道機能

（i）自覚症状，食道 $\mathrm{X}$ 線造影扣よび食道内視鏡所見 自覚的には56例中 2 例に胸やけが認められたがこの 2 症例は滑脱型食道裂孔へルニアを合併していた。 燕下障害を訴えた症例はなかった。

食道X線造影は49例になされたが先の食道裂孔へル ニアを合併した 2 症例に食道胃逆流が認められた。

食道内視鏡検查は48例になされたが先の食道裂孔一 ルニアを合併した 2 症例のらちの 1 例に食道炎が認め られたにすざなかった（表 1 )。

(ii) 食道内圧検査

術前 16 例に食道内圧検査が行われた。下部昇王帯静 止圧 (以下 LESP) の平均値は $29.8 \pm 5.7 \mathrm{~cm} \mathrm{H} \mathrm{H}_{2} \mathrm{O}(\mathrm{n}=$ 16）であった．これを食道静脈瘀からの出血の既応の 有無について検討すると，出血の既応を有する症例の LESP は28.4 $\pm 3.6 \mathrm{~cm} \mathrm{H}_{2} \mathrm{O}(\mathrm{n}=9)$ であり, 出血既応
表 1 食道静脈瘤症例の術前食道機能に関する自覚症 状及び検査所見

\begin{tabular}{|c|c|c|}
\hline $\begin{array}{l}\text { 筫覚酮状 } \\
\text { (56列) }\end{array}$ & $\begin{array}{l}\text { 胸やけ又は食道胃逆 } \\
\text { 流症状を有する症列 }\end{array}$ & 2 例 \\
\hline $\begin{array}{l}\text { X楾造影 } \\
\text { (49)! }\end{array}$ & 逆流テスト陽性例 & 2 例 \\
\hline $\begin{array}{l}\text { 内視鏡 } \\
\text { (48甽) }\end{array}$ & 食道炎を有する症例 & 1 例 \\
\hline
\end{tabular}

困 2 食道静脈瘤症例の出血の既応の有無によるLESP

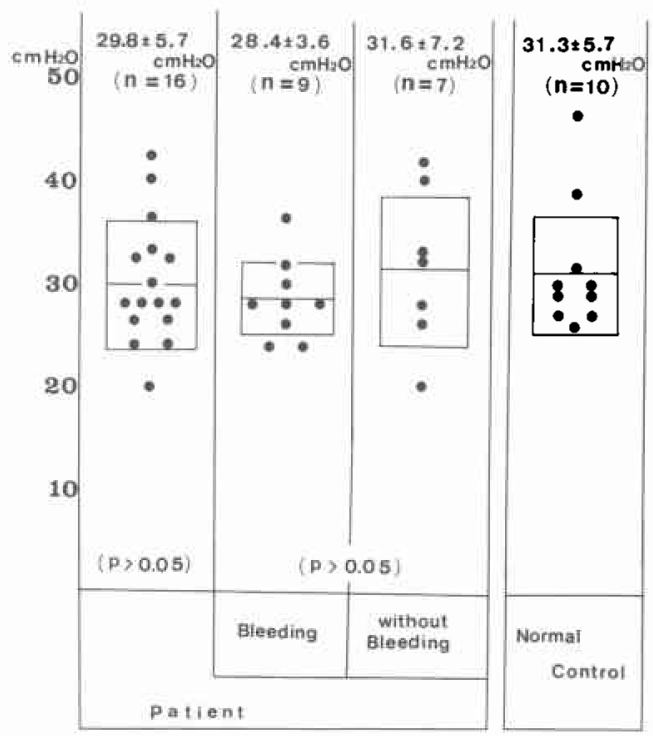

の無い症例の LESP は31. $6 \pm 7.2 \mathrm{~cm} \mathrm{H} \mathrm{H}_{2} \mathrm{O}(\mathrm{n}=7)$ 之両 者間に有意差はなく, これらの值は我々の施設の normal control の LESP 值 $31.3 \pm 5.7 \mathrm{~cm} \mathrm{H}_{2} \mathrm{O}(\mathbf{n}=10)$ と比較しても有意差は認められなかった（図2）.

2 術後遠隔成績

径胸的到達法：14例中直死 3 例を含及在院死亡例が 5 例. 再出血例 2 例, 遠隔死亡例 2 例であった。

径胸腹到達法：13例中直死 1 例で, 再出血例が 2 例, 遠隔死亡例は 3 例であった。

径胸腹横隔膜切離到達法: 29 例中直死例はなく在院 死亡例が 1 例であった. 再出血例, 遠隔死亡例は現在 まで認められなかった。(表 2)

3 術後逆流性食道炎について

(i) 自覚症状

術後在院死亡 7 例を除く 49 例の5ち, 胸やけを訴兄 た症例は径胸的到達法では 9 例中 1 例むなく, 径胸腹 到達法では 12 例中 4 例, 径胸腹横隔膜切離到達法では 28例中 6 例であった。 また胃内容物が口腔内まで逆流 すると訴えた症例は径胸的到達法では 1 例るなく，径 
表 2 食道離断術後遠隔成績

\begin{tabular}{|c|c|c|c|c|}
\hline & 症例数 & 在院死 & 再出血 & 遠隔死 \\
\hline 徍胸的到達法 & 14 & $\left(\begin{array}{l}5 \\
(3)\end{array}\right.$ & 2 & 2 \\
\hline 径胸腹到達法 & 13 & (1) & 2 & 3 \\
\hline $\begin{array}{l}\text { 径胸腹横隔膜 } \\
\text { 切離 到 達 法 }\end{array}$ & 29 & 1 & 0 & 0 \\
\hline 計 & 56 & $\begin{array}{l}7 \\
(4)\end{array}$ & 4 & 5 \\
\hline
\end{tabular}

( ): 直死例

表 3 術後逆流性食道炎に関する愁訴

\begin{tabular}{c|c|c|c}
\hline \hline & 症例数 & 胸やり & 胃内容の $^{\text {流 }}$ \\
\hline 径胸的到達法 & 9 & 0 & 0 \\
\hline 径胸腹到達法 & 12 & $\begin{array}{c}4 \\
(33.3 \%)\end{array}$ & $\begin{array}{c}3 \\
(25 \%)\end{array}$ \\
\hline $\begin{array}{c}\text { 径胸腹横隔膜 } \\
\text { 切離到 達 }\end{array}$ & 28 & $\begin{array}{c}6 \\
(23.1 \%)\end{array}$ & $\begin{array}{c}8 \\
(28.6 \%)\end{array}$ \\
\hline 計 & 49 & $\begin{array}{c}10 \\
(20.4 \%)\end{array}$ & $\begin{array}{c}11 \\
(22.4 \%)\end{array}$ \\
\hline
\end{tabular}

胸腹到達法では 3 例, 径胸腹横隔膜切離到達法では 8 例であった（表 3）。

(ii) X線造影および内視鏡所見

術後X線造影扣よびそのVTRの検査で，食道胃逆 流所見の有無をみると, 逆流所見陽性例は径胸的到達 法では 9 例中 1 例むなく, 径胸腹到達法では12例中 4 例 $(33.3 \%)$, 径胸腹横隔膜切離到達法では28例中12例 (42.9\%) にみられた。

また食道内視鏡検查で食道炎がみられた症例は径胸 的到達法では 1 例もなく, 径胸腹到達法では12例中 1 例, 径胸腹横隔膜切離到達法では28例中 3 例に認めら れた（表 4 ）。

径胸腹到達法で食道炎がみられた症例はびらん型 で，自覚的にも胸やけが強く食道離断術術後 1 年 1 力 月目に食道胃逆流防止手術としての Nissen's Fundoplication が追加された。

径胸腹横隔膜切離到達法の 3 例は軽度の発赤を呈し 色調変化型の食道炎であり自覚的にも胸やけは軽度で ありそのまま経過観察を行っている。

(iii) 食道内王検査所見

術後32例について食道内圧検查が施行された。佳胸 的到達法術後の LESP は32.2 $46.3 \mathrm{~cm} \mathrm{H} \mathrm{H}_{2} \mathrm{O}(\mathrm{n}=5)$, 径胸腹的到達法術後では29.9

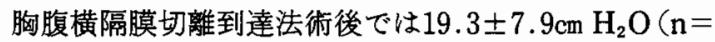
20)であった。これらの値を術前の LESP 値29.8土5.7
表 4 術後のX 線および内視鏡所見

\begin{tabular}{c|c|c|c}
\hline & 症例数 & $X$ 線逆流 & $\begin{array}{c}\text { 内視鏡 } \\
\text { 食道 }\end{array}$ \\
\hline 径胸的到達法 & 9 & 0 & 0 \\
\hline 径胸腹到達法 & 12 & $\begin{array}{c}4 \\
(33.3 \%)\end{array}$ & $1^{*}$ \\
\hline 径胸腹横隔膜 & 28 & $\begin{array}{c}12 \\
\text { 切雜到 達法 }\end{array}$ & $\begin{array}{c}3.9 \%) \\
(10.7 \%)\end{array}$ \\
\hline 計 & 49 & $\begin{array}{c}16 \\
(32.7 \%)\end{array}$ & $(8.2 \%)$ \\
\hline
\end{tabular}

*のちに Fundoplication 追加

表 5. 術後燕下障害発生率とその治療

\begin{tabular}{|c|c|c|c|c|}
\hline & 症例数 & 哑下障害 & プ范行症例 & 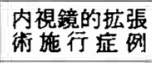 \\
\hline 径胸的到達法 & 9 & $(22.2 \%)$ & 1 & 1 \\
\hline 径胸腹到達法 & 12 & $\begin{array}{c}5 \\
(41.7 \%)\end{array}$ & (33.1\%) & 0 \\
\hline 径胸腹横隔膜 & 28 & $(78.6 \%)$ & $\begin{array}{c}16 \\
(57.196)\end{array}$ & 12 \\
\hline 計 & 49 & $\begin{array}{c}29 \\
(59.2 \%)\end{array}$ & $(42.9 \%)$ & $\begin{array}{c}13 \\
(26.5 \%)\end{array}$ \\
\hline
\end{tabular}

$\mathrm{cm} \mathrm{H}_{2} \mathrm{O}(\mathrm{n}=16)$ と比較してみると径胸的到達法, 径胸 腹到達法では有意差がみられなかったが, 径胸腹横隔 膜切離到達法では $\mathrm{p}<0.001$ で有意差をむって術後の LESP は低下した（図 3 ）。

\section{4 術後燕下障害}

(i) 自覚症状

術後在院死亡例 7 例を除く 49 例のうち, 価下困難を 訴光た症例は径胸的到達法では 9 例中 2 例 (22.2\%) であり, 径胸腹到達法では 12 例中 5 例 $(41.7 \%)$, 径胸 腹横隔膜切離到達法では28例中 22 例 $(78.6 \%)$ であっ た。すなわち49例中29例（59.2\%）に燕下困難を訴兄 た症例があり，そのうち21例 (42.9\%) に食道ブジー が行われた。 またこれら21例中13例に内視鏡的に狭窄 部の切開拡張術が施行され全例2 10 月月後には敾下 困難は消失した（表 5 ).

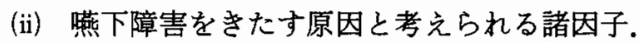

燕下障害の原因の 1 つに食道離断部の器質的狭窄が あるが，その狭窄をきたすと考えられる因子は，食道 離断部の His 角からの高さ, 傍食道血行郭清の範用, および食道の再吻合法などであろう。これらの因子に ついてその記載がはっきりしている症例47例につき， 食道ブジーがなされた症例を狭窄例として, 各到達法 別に検討した。

○食道離断の His 角からの高さ

食道離断部の His 角からの高さを， $5.0 \mathrm{~cm}$ 末满の症 
図 3 各到達法による術後 LESP

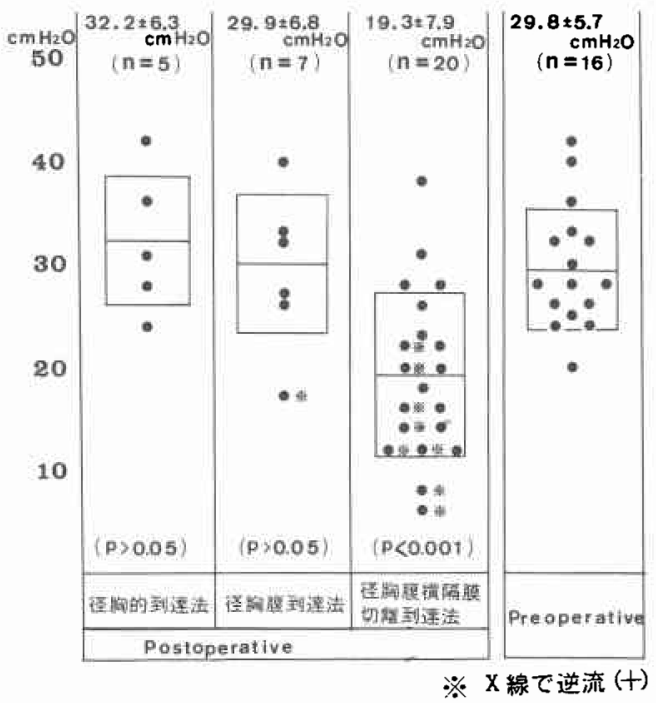

例 (5.0 cm末満群) と，5.0 cm以上の症例 $(5.0 \mathrm{~cm}$ 以上群 $)$ に分けてみると, 径胸的到達法には $5.0 \mathrm{~cm}$ 末満群 7 症例 中 1 例に術後ブジーが行われたが, $5.0 \mathrm{~cm}$ 以上群の症例 は 1 例しかなく本症例には術後狭窄は認められなかっ た。

径胸腹到達法では $5.0 \mathrm{~cm}$ 末満群 3 例中 1 例, $5.0 \mathrm{~cm}$ 以 上群 8 例中 3 例に術後狭窄が認められた。

径胸腹横隔膜切離到達法では $5.0 \mathrm{~cm}$ 末満群 22 例中 13 例， $5.0 \mathrm{~cm}$ 以上群 6 例中 3 例に術後狭窄が認められた。 全体としては $5.0 \mathrm{~cm}$ 末満群 32 例中 15 例 $(46.9 \%), 5.0 \mathrm{~cm}$ 以上群15例中 6 例 $(40.0 \%)$ に狭窄が認められたが両 群間に有意差は認められなかった（表 6 ）。

○傍食道血行郭清の範囲

傍食道血行郭清の範囲は His 角上 $8.0 \mathrm{~cm}$ から $17.0 \mathrm{~cm}$ にかけて行われた、これを $10 \mathrm{~cm}$ 以下（10 cm以下群）と $11 \mathrm{~cm}$ 以上（11 cm以上群）にわけて各到達法別に検討し た。

径胸的到達法では $10 \mathrm{~cm}$ 以下群 3 例中 1 例に狭窄がみ られた. $11 \mathrm{~cm}$ 以上群の症例は 5 例中 1 例も狭窄例はな かった。

径胸腹到達法では $10 \mathrm{~cm}$ 以下群 3 例中 1 例（33.3\%） に, $11 \mathrm{~cm}$ 以上群 8 例中 3 例 $(37.5 \%)$ に狭窄例が認め られた。

径胸腹横隔膜切離到達法では $10 \mathrm{~cm}$ 以下群 13 例中 6 例 (46.2\%) に $11 \mathrm{~cm}$ 以上群15例中10例 $(66.7 \%)$ に狭窄例 が発生した。全体として食道ブジーがなされた症例は $10 \mathrm{~cm}$ 以下群 19 例中 8 例 $(42.1 \%), 11 \mathrm{~cm}$ 以上群 28 例中 13
表 6 離断部位と狭窄（ブジー施行例）発生率

\begin{tabular}{|c|c|c|c|c|}
\hline & \multicolumn{2}{|c|}{ His 角上 $5.0 \mathrm{~cm}$ 末満群 } & \multicolumn{2}{|c|}{ His角上 $5.0 \mathrm{~cm}$ 以上群 } \\
\hline & 症例数 & ブジー施行例 & 症例数 & ブジー施行例 \\
\hline 径胸的到達法 & 7 & $(14.3 \%)$ & 1 & $\left(\begin{array}{c}0 \\
0 \%\end{array}\right)$ \\
\hline 径胸腹到達法 & 3 & $(33.3 \%)$ & 8 & $(37.5 \%)$ \\
\hline $\begin{array}{l}\text { 径胸腹横隔膜 } \\
\text { 妇 到到 羊法 }\end{array}$ & 22 & $\begin{array}{c}13 \\
(59.1 \%)\end{array}$ & 6 & $\begin{array}{c}3 \\
(50 \%)\end{array}$ \\
\hline 計 & 32 & $\begin{array}{c}15 \\
(46.9 \%)\end{array}$ & 15 & $\begin{array}{c}6 \\
(40 \%)\end{array}$ \\
\hline
\end{tabular}

表 7 傍食道血行郭清の範囲と狭窄（ブジー症例）発生率

\begin{tabular}{c|c|c|c|c}
\hline \multirow{2}{*}{} & \multicolumn{2}{|c|}{ His 角上 $10 \mathrm{~cm}$ 以下群 } & \multicolumn{2}{c}{ His 角上 $11 \mathrm{~cm}$ 以上群 } \\
\cline { 2 - 5 } & 症例数 & 狭䇤例 & 症例数 & 狭㠰挒 \\
\hline 径胸的到達法 & 3 & $\begin{array}{c}1 \\
(37.3 \%)\end{array}$ & 5 & $\left(\begin{array}{l}0 \\
0 \%)\end{array}\right.$ \\
\hline 径胸腹到達法 & 3 & $\begin{array}{c}1 \\
(33.3 \%)\end{array}$ & 8 & $\begin{array}{c}3 \\
(37.5 \%)\end{array}$ \\
\hline $\begin{array}{c}\text { 径胸腹横隔膜 } \\
\text { 切離到 達法 }\end{array}$ & 13 & $\begin{array}{c}6 \\
(46.2 \%)\end{array}$ & 15 & $\begin{array}{c}10 \\
(66.7 \%)\end{array}$ \\
\hline 計 & 19 & $\begin{array}{c}8 \\
(42.1 \%)\end{array}$ & 28 & $\begin{array}{c}13 \\
(46.4 \%)\end{array}$ \\
\hline
\end{tabular}

例 (46.4\%) であった（表7）.

○吻合方法

食道離断部再吻合には atraumatic needle 付ポリエ ステル系(Ticron, Tevdec)，あるいは PGA 系(Dexon) る使用し結節吻合を行ってきたが，最近は消化管自動 吻合器 EEA を使用している，筋層を切開し粘膜層だ けにEEAをかけ，離断吻合を完了する。

この EEA を使用した症例と，結節手縫い吻合を 行った症例とを比較してみると，手縫い吻合17例中 8 例 $(47.1 \%)$, EEA11例中 8 例 $(72.7 \%)$ の症例に狭窄 が発生した（表 8).

5 食道離断術後アカラシア様変化

食道離断術後食道X線造影にて傍食道血行郭清以下 の tapered narrowing が認められる症例があり，あた かもアカラシア様所見を呈し燕下障害を訴える。こ れらの所見に注目し最近食道X線造影およびVTRを

表 8 吻合方法と狭窄（ブジー施行症例）発生率

\begin{tabular}{c|c|c|c|c}
\hline \hline & \multicolumn{2}{|c|}{ 手繾い結節吻合 } & \multicolumn{2}{c}{ EEA 自動吻合器 } \\
\cline { 2 - 5 } & 症例数 & 狭窄例 & 症例数 & 狭智例 \\
\hline 径胸的到達法 & 8 & 1 & 0 & \\
\hline 径胸腹到達法 & 11 & 4 & 0 & \\
\hline $\begin{array}{c}\text { 径胸腹横隔膜 } \\
\text { 切離 到 達 法 }\end{array}$ & 17 & $\begin{array}{c}8 \\
(47.1 \%)\end{array}$ & 11 & $\begin{array}{c}8 \\
(72.7 \%)\end{array}$ \\
\hline
\end{tabular}


用い, 食道のアカラシア様変化の有無を検し，さらに 食道内王検査にて傍食道血行郭清部以下の食道蠕動の 伝達の有無とEGJの relaxation の有無, および LESPとの関連について検討した。

X線造影および VTRにて tapered narrowing を認 めた症例は術後早期のものに多く, 1 年以降の症例に は認められなかった。
食道内王検查では EGJの relaxation が認められな かった症例は術後 4 カ月以内の症例に多かった。 ま た傍食道血行郭清部以下の食道蠕動の伝達もやはり術 後 4 カ月以内では認められない症例が多かつた（表 9).

図 4 は52歳女性, 径胸腹横隔膜切離到達法による食 道離断術後14日目の食道 $\mathrm{X}$ 線造影と食道内王曲線であ

* 表 9 食道離断術後食道機能検查所見

\begin{tabular}{|c|c|c|c|c|c|}
\hline \multirow[b]{2}{*}{ 症 例 } & \multirow{2}{*}{$\begin{array}{l}\text { 術後検查 } \\
\text { までの期間 }\end{array}$} & \multirow[b]{2}{*}{$\begin{array}{l}X \text { 線造影 } \\
\text { アカラ様所見 }\end{array}$} & \multicolumn{3}{|c|}{ 食道内圧所見 } \\
\hline & & & Relaxation & 嫊動 & $\begin{array}{c}\text { LESP } \\
\left(\mathrm{cmH}_{2} \mathrm{O}\right)\end{array}$ \\
\hline 790016 & 1 年 8 力月 & - & + & + & 12.0 \\
\hline 790593 & 1 年 3 力月 & - & + & + & 12.0 \\
\hline 791004 & 11力月 & - & + & + & 6.0 \\
\hline 790279 & 1 年 & - & + & + & \\
\hline 800001 & 9 力月 & + & + & + & 16.0 \\
\hline 800045 & 1.5 力月 & + & - & - & 8.0 \\
\hline 800569 & 4 力月 & + & - & - & 16.0 \\
\hline 801032 & 1 力月 & + & - & - & 10.0 \\
\hline 801045 & 2 力月 & + & - & + & 8.0 \\
\hline 801055 & 2 週 & + & - & - & 6.0 \\
\hline 801090 & 3 週 & - & - & + & 24.0 \\
\hline 801131 & 3 週 & + & - & - & 22.0 \\
\hline 801135 & 2 週 & + & - & + & 10.0 \\
\hline
\end{tabular}

図 4 食道離断術後の食道X線造影と食道内圧曲線一術後14日目（径胸腹横隔膜切離 到達法）

No. 800734 52y. Female

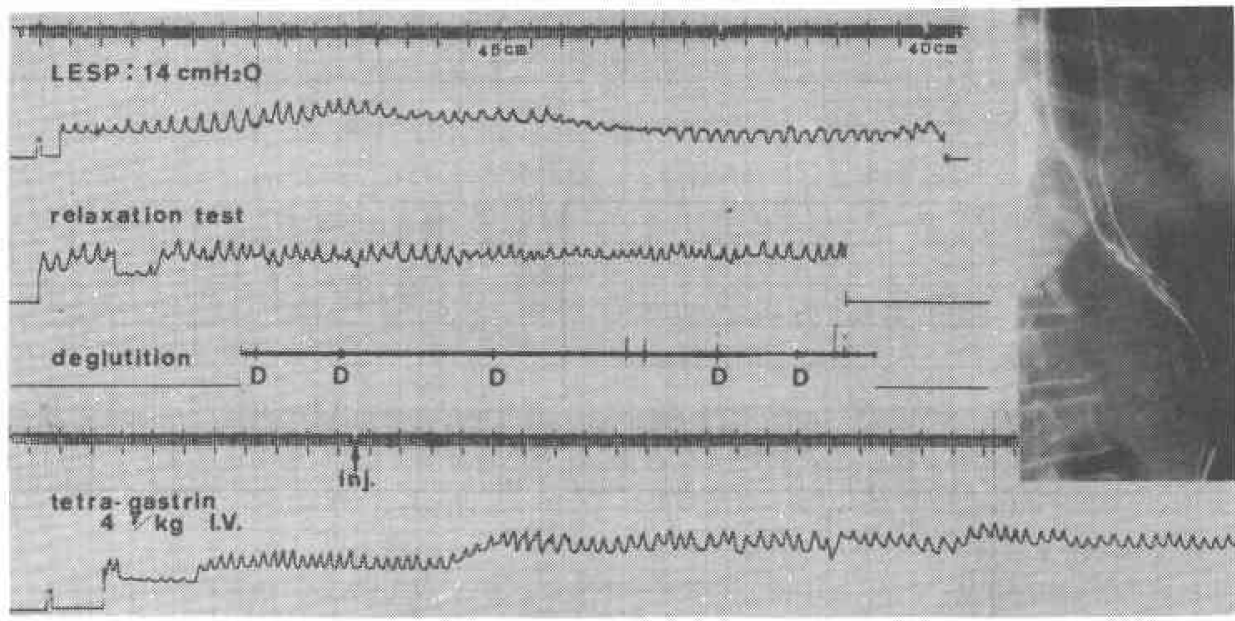


図 5 食道離断術後の食道X線造影と食道内圧曲線一術後 1 年 8 力月（径胸腹横隔膜 切離到達法)

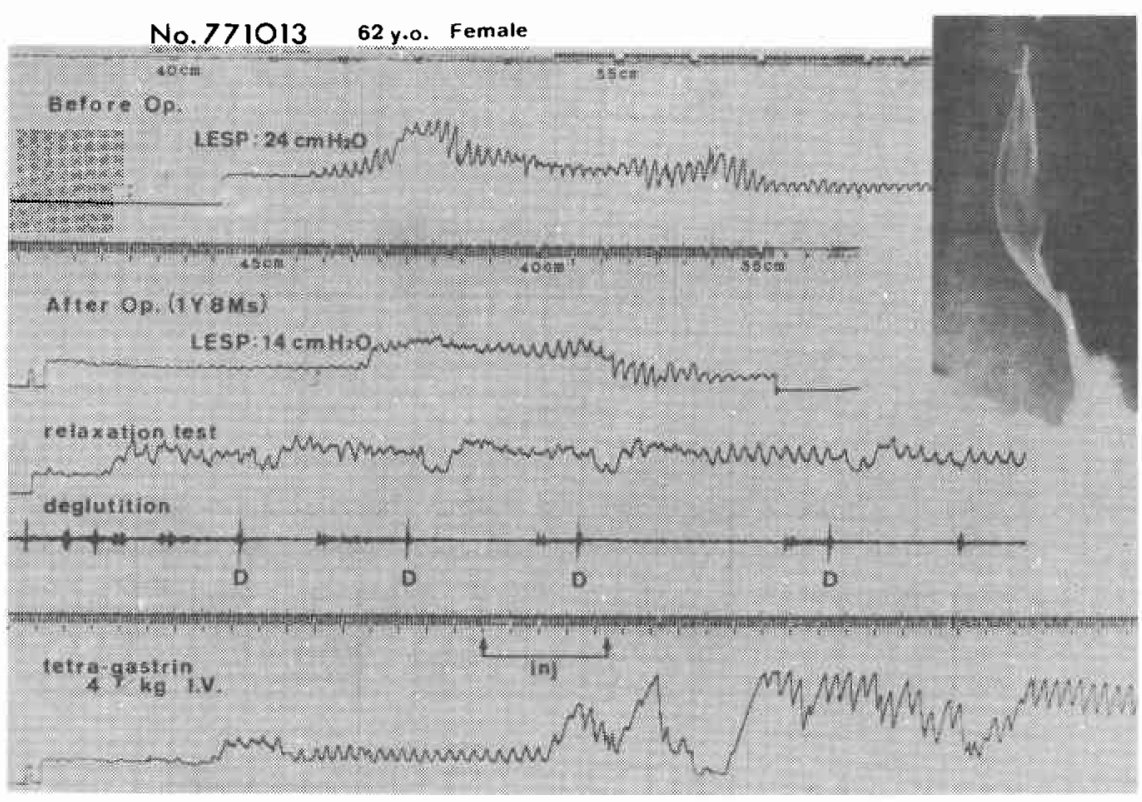

る. 食道 $\mathrm{X}$ 線造影では血行郭清部以下食道の tapered narrowing がみられる。食道内圧曲線では，上段は静 止引き抜き曲線であるが LESP は $14 \mathrm{~cm} \mathrm{H}_{2} \mathrm{O} て ゙$ 著明に 低下していた。中段は relaxation testである。経口 的に水 $5.0 \mathrm{cc}$ 嬩下させた時(D)にその嚥下運動に反応 して EGJ は relaxationを起し, 正常では LESP が胃 内圧まで低下するのであるが, 本例では認められない， 下段は tetra-gastrin $4 \mu \mathrm{g} / \mathrm{kg}$ 静注前後の LESPを持 続的に記録したものであるが, tetra-gastrin 静注後 LESP の若干の上昇は認められるが，正常に比しその 反応は非常に弱いものである。

図 5 は術後 1 年 8 力月の症例である. 食道X線造影 ではもはや tapered narrowing は認められない，食道 内圧曲線の最上段怯術前の内圧曲線で LESP は $24 \mathrm{~cm}$ $\mathrm{H}_{2} \mathrm{O}$ である。二段目は術後 1 年 8 カ月のものでLESP は14cm $\mathrm{H}_{2} \mathrm{O}$ と低い. しかし 3 段目の relaxation test では燕下運動(D)に反応してょく relaxation が認 められる。ささらに最下段の tetra-gastrin $4 \mu \mathrm{g} / \mathrm{kg}$ 静注 負供にても LESP は著明な上昇を示した。

\section{IV 考 察}

食道離断術の目的は静脈瘤からの出血の防止にあ り，そのためには食道に流入する門脈系の側副血行路 をすべて遮断しなくてはならない, 左胃静脈系, 短胃 静脈系さらに後腹膜空, 後粉隔からの側副血行をでき
るかぎり遮断するには, 結局胃上部から胸部食道にか けて広範囲に亘る血行郭清が要求される。しかし術後 の食道機能の障害を少なくするには，できるだけこの 血行郭清の範囲を狭くしたい.すなわち出血を確実に 防止し，乙か子術後食道機能が正常に保たれるよらな 術式を理想とする。このために最近では腹腔側からだ けのアプローチによって食道離断術を行っている施設 もある ${ }^{4,5)}$. 李た肝に対する影響から考学ると開胸だけ で経横隔膜的アプローチの方が開腹よりも秀れてい る6).このように食道離断術の方法にはいろいろな 困難な問題が含まれていていまだ最良の術式はみあた らない現状である。

1 術前食道機能について

食道静脈瘤症例では LES の機能不全があり逆流性 食道炎を発生しそのために静脈瘤の破裂を引き起すと いら報告もみられるが7), 一方食道静脈瘤症例でも LESP は正常人の值と差はなく ${ }^{8,9)}, \mathrm{pH}$ 電極によって も食道胃逆流現象は正常人と全く同率でありとくに食 道静脈瘤症例に LES の機能不全は認められず静脈瘤 の破裂に逆流性食道炎は関与しない(1011) といら報告も みられる。

われわれの今回の検索では自覚症状, 食道X線造影 および食道内視鏡検査にて逆流性食道炎を示唆する症 例は56例中 2 例にみられたが，この 2 例はいずれも滑 
脱型食道裂孔へルニアを合併している症例であった． また食道内圧検查では，出血の既応の有無による LESPの差はなく，これらの値はわれわれの normal control と有意差はなく食道静脈瘤症例の LES 機能 は正常と考学られた。

2 術後逆流性食道炎について

食道離断術後は当然 LES 機構は破壊され同部の機 能不全をさたすことが考劣られる、実際に術後逆流性 食道炎をさたした症例も報告されている 逆流性食道炎を防止する意味において逆流防止の附加 手術，または術式の工夫がなされている4)1314)15).

また一方では食道離断術後でも LESの機能はよく 温存され, 逆流性食道炎の発生はみられないとの報告 あある416)

われわれの今回の検討では径胸的到達法では食道胃 逆流を疑わせる所見を呈した症例は全くなかったが， 径胸腹到達法, 径胸腹横隔膜切離到達法では的 $30 \%$ の 症例に逆流症状が認められた。安際にX線造影㧍 よびその VTRにて径胸的到達法の症例には逆流は 1 例も認められなかったが, 径胸腹到達法では33.3\%に, 径胸腹横隔膜切離到達法では $42.9 \%$ に逆流が証明され た。

しかし実際に内視鏡的に強い逆流性食道炎が認めら れた症例は径胸腹到達法による1例だけであった。

われわれは迷走神経本幹, および Latarjet の神経枝 は温存しあたかも近位迷切術の要領で血行を郭清して いる、そのため幽門形成術は行わず，逆流防止附加手 術毛行っていない.

これらの操作により胃液酸度もかなり低下し，逆流 性食道炎の発生も少ないのではないかと考えている。 実際に食道離断術後の減酸率は tetra-gastin 法による MAO で51\%， Insulin 法で $81 \%$ という報告がみられ $ろ^{17)}$.

迷走神経本幹が切断された場合には当然胃内容物の 停滞を防止するために幽門形成術が必要であろう。 しかしこの様な病態は，すなわち食道離断術後 LES 機 能が低下し容易に食道胃逆流現象が発生し，さらに幽 門形成が行われている状態はあたかも胃上部切除を行 い，食道胃吻合および幽門形成術がなされた病態と同 様であり, 後者の際胆汁の逆流による食道炎の発生率 は高頻度にみられまた高度の炎症が発生することはよ く知られた事実である。これらのことを考慮すれば 迷走神経幹が切断されたと考えられる場合には，幽門 形成と同時に食道胃逆流防止附加手術を行うべきであ
ろ5.

3 術後離断吻合部の狭窄について

術後離断吻合部の狭窄の原因については種々考えら れている.たとえば井口は離断部の高さを考えていて, $\mathrm{EGJ}$ 上 $2.0 \mathrm{~cm}$ で離断吻合を行ったところ 4 例中 3 例に 狭窄が発生し，EGJ上 $5.0 \mathrm{~cm}$ で行ったところ 3 例中 1 例に軽度の狭窄を認めたにすぎなかったとしてい $ろ^{18) 19)}$.

われわれの症例では離断部位の高さでは狭窄発生率 に差はみられなかった。

本術式はもともと食道の阻血を目的とするすのであ るが，術後再出血をきたさず，しかも食道吻合部の創 傷治瘾が充分に行えるだけの血流は保存すべきであ り，この点目的と機能が相反し血行郭清の方法执よび 範曲が一番重要視される。われわれの症例では径胸的 到達法では狭窄例が少なく, 径胸腹横隔膜切離到達法 で最も多く狭窄が発生した。径胸腹到達法と径胸腹 横隔膜切離到達法は, 基本的にはその血行郭清手技叔 よび離断吻合の手技も同様であるが, 径胸腹到達法で は食道裂孔部の血行郭清が若干不徹底さを欠いたので はないかと考えられる。ちなみに本到達法13例中 2 例 に術後遠隔再出血例がみられた。しかし径胸腹横隔膜 切離到達法では同一術野で, 胸腔側, 腹腔側から食道 裂孔部を操作することができ，より徹底した血行郭清 が行われるようになった。しかし His 角より $11 \mathrm{~cm}$ 以上 の血行郭清群と $10 \mathrm{~cm}$ 以下群で比較すると, $11 \mathrm{~cm}$ 以上群 に狭窄例が多く発生していることよりやはり狭窄発生 の原因は，血行郭清の範囲が主なものであろう．しか し10cm以下群でもその $46.2 \%$ に狭窄が発生しているこ とはさらに検討を要する。

消化管自動吻合器はり連で開発され食道空腸吻合, 下部大腸吻合などに用いられてさたが20121)離断吻合操 作が容易でかつ確実なため最近では食道離断術に好ん で使われるようになった22)23(24)25)26). しかし手縫い結 節吻合よりも若干狭窄例の発生が多かったとする報告 がみられる23)25)。市た宮園はPKS25-Mを使用し $59.4 \%$ 狭窄例発生率を報告した ${ }^{27)}$.

自動吻合器 EEA を使用した場合と Gambee 吻合を 比較し吻合部の血流量は EEA に有意に低下し，吻合 部䈍合は若干 EEA に遅く，肉芽形成は強いとの報告 がある ${ }^{28,29)}$ が，諸家の報告では自動吻合器を使用して も経腹的食道離断では狭窄例が少なく，開胸開腹で行 らと多い25)とする報告がみられる。

われわれの症例では手縫い結節吻合で $47.1 \%$, EEA 
で72.7\%の狭窄例発生率であり, EEA に狭窄発生が多 い傾向にあったが，症例数が少なく統計的には有意差 はみられなかった。

4 食道離断術後アカラシア様変化について,

食道離断術後器質的狭窄があまりみられないのに術 後早期に曖下障害を訴觉る症例があり，X線造影では 血行郭清部以下食道の tapered narrowing が認めら れた。

このような現象は近位迷切術後に報告され，そのほ とんどは術後 3 力月以内に自然に自覚症状の改善がみ られている ${ }^{30131)}$.

われわれもこのような観点から食道X線造影，扣よ びVTR と食道内压検查による relaxation の有無, 食 道蠕動波の伝達, LESP などを対比してみると, 術後 2 週から 4 カ月の症例では tapered narrowing を示し， EGJ の relaxation が不完全または欠如しているもの がある.しかし 1 年前後の症例では LESP はいまだに 低值を示する relaxation 扣よび蠕動の伝達は回復し ている。 これらの変化は阻血性の変化も考克られる が, やはり denervationの影響が最も強いものであろ 5.

\section{結 語}

食道静脈瘤56症例の食道離断術前後の食道機能につ き自覚症状, 食道X線造影抽よびVTR, 内視鏡, 内圧 検査を行い検討した。

(1) 術前の食道機能は正常でLES 圧も $29.8 \pm 5.7 \mathrm{~cm}$ $\mathrm{H}_{2} \mathrm{O}(\mathrm{n}=16)$ とよく保たれ出血の有無でも LES 圧に差 がみられなかった。

(2) 術後ではX線造影で約 $33 \sim 43 \%$ に食道胃逆流が みられ LES 圧は $19.3 \pm 7.9 \mathrm{cmH}_{2} \mathrm{O}(\mathrm{n}=20)$ と LES 機 能は低下した。びらん型食道炎が 1 例にみられたが他 は自覚症状もなく軽微なすのであった。

（3）術後早期の曣下障害の原因には下部食道のアカ ラシア様変化が関与していることが示峻された。

(4) 離断吻合部の狭窄は $42.9 \%$ 症例に発生し現在 われわれが行っている $10 \mathrm{~cm}$ 以上の傍食道血行の郭清範 囲が広すぎるものと考兄られた。自動吻合器 EEA 使 用症例に狭窄発生率が高い傾向にあったが統計的に有 意差はなかった。

本論文の要旨は昭和56年 2 月 26 日第 17 回日本消化器外科学 会総会(長崎), ワークショップI,「消化管術後の障害」K て発表した。

\section{参考文献}

1）田代征記ほか：左開胸経横隔膜開腹による食道離
断術. 手術, 34:257-263, 1979.

2）大熊利忠浮か：食道胃接合部に対する各種手術侵 襲の食道内圧に及济寸影響. 日消外会誌, 12 ： 508-513， 1979.

3）原田貞美仂：各種食道疾患の LESP一特に術中 モニターとしての食道内圧測定の意義一。外科診 療, $21: 1223-1226.1979$.

4）平島毅ほか：食道静脈瘤に対する経腹的食道粘 膜離断術とその長期経過例の検討. 外科, 40 ： 1337-1340, 1978.

5）高崎 健娃か：食道静脈瘤に対する経腹的食道離 断術一経胸的食道離断術との血行郭清の相違点に ついての考察一. 日消外会誌, $13: 759-765,1980$

6）朔元則浮か：食道静脈瘤に対する直達手術の検 討一とく以耐糖能㧍よび肝循環の面からみた経 胸, 腹到達経路の比較.日消外会誌, 11：631-635. 1978.

7) Wangenknecht T.W. et al. : Nature of Bleeding in Esophageal Varices. Surgery, 33: 869-874, 1953.

8) Eckardt V.F. et al.: Does Lower Esophageal Sphincter Incompetency Contribute to Esophageal Variceal Bleeding. Gastroenterology, $71: 185-189,1976$.

9）岩崎 甫注か：食道静脈瘤症例の静止時食道内圧 の検討. 日消病会誌，76：507，1979.

10) Eckardt V.F. et al. : Gastroesophageal Reflux and Bleeding Esophageal Varices. Gastroenterology, 76: 39-42, 1979

11）白羽 誠法か：LESPよりみた食道静脈瘤破綻の 機序。日消病会誌, $76: 969,1979$.

12）芦田寛伍か：食道静脈瘤手術の遠隔成績一直達手 術例と選択的シャント手術例を比較して一。日消 病会誌, $76: 507,1979$.

13）青木照明浮か：経腹的食道離断術一Nissen Fundoplicationの応用. 日消外会誌, $12 ： 72,1979$.

14）笽福哲彦ほか：Fundic patch 法を用いた食道離 断術。日消外会誌, $12: 72,1979$.

15）杉町圭蔵活か：食道静脈瘤に対寸る直達手術之逆 流性食道炎。日消外会誌，12：11，1979.

16）杉浦光雄注か：食道静脈瘤に対する直達手術と逆 流性食道炎。日消外会誌，12：12，1979.

17）園田化志汸か：われわれの食道静脈瘤手術の選択 的近位迷切後の胃分泌拉よび運動におよぼす影響 の検討. 日消外会誌, $11: 882,1978$.

18）井口 潔：胸腹部境堺領域疾患としての食道静脈 瘤. 日胸外会誌, $27 ： 413-418,1979$.

19)朔 元則汪か：食道静脈瘤出血に対する手術適応 之術式の選択. 手術, 33：639-647, 1979.

20) Goligher J.C. et al. : Experience with the Russian Model-249 Suture Gun for Anastomosis of the Rectum. Surg. Gynecolo. \& 
Obstet., $148: 517-524,1979$.

21) Ravitch M.M., Steinchen F.M.: A stapling Instrument for End to-End Inverting Anastomosis in the Gastrointestinal Tracts. Ann. Surg., 189: 791-797, 1979.

22) Peracchia A. et al.: A New Tecnique for the Treatment of Esophageal Bleeding in portal Hypertension. Internal Surgery, 65: 401-404, 1980.

23）高崎 健ほか：腸管吻合器応用による経腹的食道 離断術の遠隔成績，肝臓，20：539. 1979.

24）岡芹繁夫ほか：縫合器使用による経腹的食道離断 術. 日消病会誌, $76: 1201,1979$.

25）宮園 光ほか：食道静脈瘤に対する腸管吻合器に よる食道離断術症例の検討. 第29回食道疾患研究 会 (東京) 抄録集, 45頁, 1980 .

26）平島毅法か：食道粘膜離断の工夫一器械
（EEA）による自動縫合法。外科，43：517-521， 1981

27）宮園 光, 秋山 洋: 食道離断術に対するソ連製 腸管吻合器の使用経験. 外科, $41: 1451-1454$, 1979.

28）北島政樹，相馬 智：消化管吻合創の治矬からみ た器械吻合と Gambee 吻合の比較検討. 臨床外 科, 35：1279-1287，1980

29）北島政樹, 相馬 智：吻合部治套機転からみた器 械吻合の検討. 消化器外科, 4(1):25-33, 1981

30) Skjennald A. et al. : Dysphagia after Proxymal Gastric Vagotomy. Scand. J. Gastroent., 14 : $609-613,1979$.

31）生越喬二ほか：迷走神経切断術後に生ずる苝下障 害の発生機序とその経時的変化について，日消外 会誌, $14: 197,1981$. 